
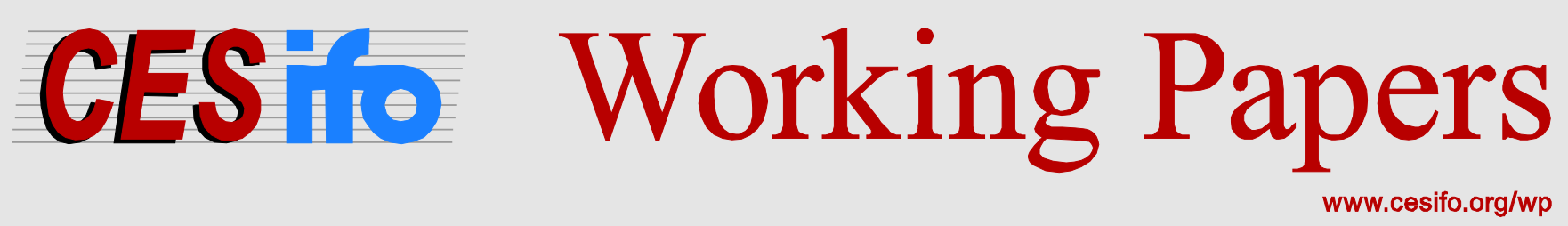

\title{
Pharmaceutical Innovation, Longevity, and Medical Expenditure in Greece, 1995-2010
}

\author{
Frank Lichtenberg
}

\author{
CESIFO WORKING PAPER NO. 5166 \\ CATEGORY 3: SOCIAL PROTECTION JANUARY \\ 2015
}

ISSN 2364-1428
An electronic version of the paper may be downloaded
- from the SSRN website: Www.SSRN.com
- from the RePEc website: Www.RePEc.org
- from the CESifo website: www.CESifo-group.org/wp

\section{CESifo}




\title{
Pharmaceutical Innovation, Longevity, and Medical Expenditure in Greece, 1995-2010
}

\begin{abstract}
Longitudinal, disease-level data are used to analyze the impact of pharmaceutical innovation on longevity (mean age at death), hospital utilization, and medical expenditure in Greece during the period 1995-2010. The estimates indicate that pharmaceutical innovation increased mean age at death by 0.87 years (10.4 months)-_about $44 \%$ of the total increase in longevity-and that diseases with larger increases in the cumulative number of drugs launched 1-4 years earlier had smaller increases in the number of hospital days. Real per capita pharmaceutical expenditure increased rapidly during this period, but $62 \%$ of the increase in pharmaceutical expenditure was offset by a reduction in hospital expenditure attributable to pharmaceutical innovation. The baseline estimate of the cost per life-year gained from pharmaceutical innovation in Greece is $\$ 17,117$, which is a very small fraction of leading economists' estimates of the value of (or consumers' willingness to pay for) a oneyear increase in life expectancy.
\end{abstract}

JEL-Code: I120, J110, L650, O330, O520.

Keywords: pharmaceutical, innovation, longevity, Greece, hospital.

Frank Lichtenberg

Graduate School of Business

Columbia University

3022 Broadway

USA - 10027 New York NY

frank.lichtenberg@columbia.edu 


\section{Introduction}

Longevity increase is increasingly recognized by economists to be an important part of economic growth and development (Nordhaus, 2002; Murphy and Topel, 2005). Economists have also come to recognize that, in the long run, the rate of economic "growth...is driven by technological change that arises from intentional [research and development (R\&D)] investment decisions made by profit-maximizing agents" (Romer ,1990) and by public organizations such as the National Institutes of Health. In principle, technological change could be either disembodied or embodied in new goods. Solow (1960) hypothesized that most technological change is embodied: to benefit from technological progress, one must use newer, or later vintage, goods and services. Bresnahan and Gordon (1996) argued that "new goods are at the heart of economic progress." Grossman and Helpman (1991) argued that "almost every product exists on a quality ladder, with variants below that may already have become obsolete and others above that have yet to be discovered," and that "each new product enjoys a limited run at the technological frontier, only to fade when still better products come along." Hercowitz (1998, p. 223) also reached the "conclusion...that 'embodiment' is the main transmission mechanism of technological progress to economic growth."

This paper will analyze the impact of pharmaceutical innovation (i.e., the utilization of new drugs) on longevity and medical expenditure in Greece during the period 1995-2010. The medical substances and devices industries are the most research intensive industries in the economy (National Science Foundation, 2013). Pharmaceuticals are also more researchintensive than other types of medical care: in 2007, prescription drugs accounted for $10 \%$ of U.S. health expenditure (Center for Medicare and Medicaid Services, 2013: Table 2), but more than half of U.S. funding for biomedical research came from pharmaceutical and biotechnology firms (Dorsey et al, 2010). Moreover, new drugs often build on upstream government research (Sampat and Lichtenberg, 2011).

The overall impact of pharmaceutical innovation on longevity and health can be assessed in a variety of ways. ${ }^{1}$ Each approach has advantages and disadvantages. One approach is to survey a large number of case studies of specific drugs or classes of drugs. Two problems with

\footnotetext{
${ }^{1}$ For a review of the literature on the impact of medical innovation in general, see the 604-page report prepared by the Australian Productivity Commission (2005).
} 
this approach are (1) the specific drugs examined may not constitute a representative sample, and (2) different methods and metrics are used in each study, making it difficult to draw general conclusions.

A second approach is to conduct econometric studies of drugs in general. Several types of econometric studies of drugs in general can be performed. One can perform studies using patient-level data, to investigate the following question: do patients using newer drugs live longer than patients using older drugs, controlling for their demographic characteristics (age, sex, race, income, education, etc.), medical conditions, behavioral risk factors, and other variables ${ }^{2}$ Alternatively, one can perform studies using aggregate data, preferably longitudinal (panel) data. $^{3}$ There are two main types of studies based on aggregate panel data. One can analyze longitudinal region-level data, to investigate the following question: has life expectancy increased more rapidly in regions (e.g. states or countries) experiencing more pharmaceutical innovation, controlling for changes in income, education, and other variables? ${ }^{4}$

One can also analyze longitudinal disease-level data, to determine whether life expectancy has increased more rapidly for people with diseases experiencing more pharmaceutical innovation. A potential advantage of this approach is that variation across diseases in the pace of pharmaceutical innovation may be "more exogenous" (e.g. due to heterogeneous scientific opportunity) than variation across individuals or regions. This approach has been applied to U.S. data (Lichtenberg ,2007, 2009).

Several recent studies have shown that prescription drug cost-sharing, which affects the quantity of pharmaceutical consumption, has a "spillover effect" on hospital utilization. One study (Chandra et al, 2010) found a "rather modest offsetting rise in hospital care when physician and prescription drug copayments are raised, but...substantial offsets for the sickest populations with chronic diseases" (p. 211). Another study (Karaca-Mandic et al, 2012) found that "greater cost sharing for asthma medications was associated with a slight reduction in medication use and higher rates of asthma hospitalization among children aged 5 years or older” (p. 1284).

\footnotetext{
${ }^{2}$ Lichtenberg et al (2009) studied the impact of pharmaceutical innovation on longevity using patient-level data on elderly residents of Quebec, and Lichtenberg (2013) studied this issue using patient-level data on elderly Americans. ${ }^{3}$ Grunfeld and Griliches (1960: p. 1) showed that "aggregation of economic variables can, and in fact frequently does, reduce...specification errors. Hence, aggregation does not only produce an aggregation error, but may also produce an aggregation gain.” In particular, patient-level data are surely more subject to selection effects (the sickest patients might get the newest—or oldest—-treatments) than aggregate data.

${ }^{4}$ Lichtenberg (2011) studied the impact of pharmaceutical innovation on longevity using longitudinal state-level U.S. data, and Lichtenberg (2012a) studied this issue using longitudinal state-level German data,
} 
Pharmaceutical innovation may have a spillover effect on hospital utilization, because it tends to increase the quality (and perhaps also the quantity) of pharmaceutical consumption. Even though pharmaceutical innovation is very likely to increase pharmaceutical expenditure, if it reduces hospital expenditure, it may not increase (and could even reduce) total medical expenditure. $^{5}$

For this study, longitudinal, disease-level data were obtained from several rich databases (Thériaque, the WHO Mortality Database, Greek Statistical Authority, and the IMS Health MIDAS database) to examine the impact of pharmaceutical innovation on longevity, hospital utilization, and medical expenditure in Greece during the period 1995-2010. ${ }^{6}$ By combining the estimates of the effect of pharmaceutical innovation on longevity and medical expenditure, the incremental cost-effectiveness (cost per life-year gained) of pharmaceutical innovation in Greece during the period 1995-2010 can be estimated.

In the next section, equations to estimate the impact of pharmaceutical innovation on longevity and hospital utilization will be presented. Data sources are described and descriptive statistics are presented in section 3. Estimates of econometric models are presented in section 4. The cost-effectiveness of pharmaceutical innovation in Greece is assessed in Section 5. The final section contains a summary and conclusions.

\section{Econometric models for estimating the impact of pharmaceutical innovation on longevity and hospital utilization}

\section{A. Longevity model}

In his model of endogenous technological change, Romer (1990) hypothesized an aggregate production function such that an economy's output depends on the "stock of ideas" that have previously been developed, as well as on the economy's endowments of labor and capital. The longevity model that will be estimated below may be considered a health production function, in which longevity (age at death) is an indicator of health output or outcomes, and the cumulative number of drugs approved is analogous to the stock of ideas. The model will be of the following form:

\footnotetext{
${ }^{5}$ Newhouse (1992) observed that "technological change is not necessarily expenditure-increasing" (p. 11), and that "hospital expenditure is the single largest component of the overall expenditure increase" (p. 12).

${ }^{6}$ Patient-level and longitudinal region-level data for Greece are not available.
} 


$$
\text { AGE_DEATH }_{\mathrm{it}}=\beta_{\mathrm{k}} \mathrm{N}_{-} \text {CHEM_SUBSTANCES } \mathrm{i}_{\mathrm{i}, \mathrm{t}-\mathrm{k}}+\alpha_{\mathrm{i}}+\delta_{\mathrm{t}}+\varepsilon_{\mathrm{it}}
$$

where

$$
\begin{aligned}
& \text { AGE_DEATH } \mathrm{At}_{\mathrm{it}} \quad=\text { mean age at death from disease } \mathrm{i} \text { in year } \mathrm{t}(\mathrm{t}= \\
& 1995, \ldots, 2010) \\
& \text { N_CHEM_SUBSTANCES } \mathrm{i}_{\mathrm{i}, \mathrm{t}-\mathrm{k}}=\sum_{\mathrm{d}} \mathrm{IND}_{\mathrm{di}} \mathrm{APP}_{\mathrm{d}, \mathrm{t}-\mathrm{k}}=\text { the number of chemical substances } \\
& \text { (drugs) to treat disease } \mathrm{i} \text { commercialized by the end of year } \mathrm{t}-\mathrm{k} \\
& \mathrm{IND}_{\mathrm{di}}=1 \text { if drug } \mathrm{d} \text { is used to treat (indicated for) disease } \mathrm{i} \\
& =0 \text { if drug } \mathrm{d} \text { is not used to treat (indicated for) disease } \mathrm{i} \\
& \mathrm{APP}_{\mathrm{d}, \mathrm{t}-\mathrm{k}}=1 \text { if drug } \mathrm{d} \text { was commercialized by the end of year } \mathrm{t}-\mathrm{k} \\
& =0 \text { if drug } \mathrm{d} \text { was not commercialized by the end of year } \mathrm{t}-\mathrm{k} \\
& \alpha_{\mathrm{i}}=\mathrm{a} \text { fixed effect for disease } \mathrm{i} \\
& \delta_{\mathrm{t}}=\mathrm{a} \text { fixed effect for year } \mathrm{t}
\end{aligned}
$$

Inclusion of year and disease fixed effects controls for the overall increase in Greek longevity and for stable between-disease differences in longevity. A positive and significant estimate of $\beta_{\mathrm{k}}$ in eq. (1) would signify that diseases for which there was more pharmaceutical innovation had larger increases in longevity. Eq. (1) will be estimated by weighted least-squares, weighting by the number of deaths caused by disease i in year t. Standard errors will be clustered within diseases.

If this model is correctly specified, it will enable determination of how much of the increase in mean age at death during the sample period (1995-2010) can be attributed to the introduction of new drugs. The expression $\left(\delta_{2010}-\delta_{1995}\right)$ indicates the 1995-2010 increase in longevity, controlling for (holding constant) the number of drugs, i.e., in the absence of pharmaceutical innovation. Suppose eq. (1) is estimated, excluding

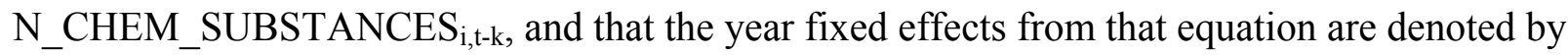
$\delta_{\text {t }}$. Then $\left(\delta^{\prime}{ }_{2010}-\delta^{\prime}{ }_{1995}\right)$ indicates the $1995-2010$ increase in longevity, not holding constant the number of drugs, i.e., in the presence of pharmaceutical innovation, and $\left(\delta^{\prime}{ }_{2010}-\delta^{\prime}{ }_{1995}\right)-\left(\delta_{2010}-\right.$ $\delta_{1995)}$ is an estimate of the $1995-2010$ increase in longevity attributable to pharmaceutical innovation. 
Life expectancy at birth is probably the most commonly cited measure of longevity, but the measure of life expectancy to be analyzed is mean age at death. ${ }^{7}$ The main reason is that life expectancy at birth (or at higher ages) cannot be measured for specific diseases. A more minor "disadvantage" of this indicator is that it is "hypothetical," rather than "actual": it is based on the period life table, which describes what would happen to a hypothetical (or synthetic) cohort if it experienced throughout its entire life the mortality conditions of a particular time period (Arias, 2010).

Mean age at death and life expectancy at birth (LE_BIRTH) are both probabilityweighted averages of age at death:

$$
\begin{aligned}
\text { AGE_DEATH } & =\sum_{\mathrm{a}} \mathrm{p}_{1 \mathrm{a}} \mathrm{a} \\
\text { LE_BIRTH } & =\sum_{\mathrm{a}} \mathrm{p}_{2 \mathrm{a}} \mathrm{a}
\end{aligned}
$$

where a denotes age at death, and $p_{1 \mathrm{a}}$ and $\mathrm{p}_{2 \mathrm{a}}$ are probabilities of dying at age a. In the case of AGE_DEATH, the probabilities depend only on the number of deaths at each age: $p_{1 \mathrm{a}}=$ N_DEATHS $/$ / $\sum_{\mathrm{a}} \mathrm{N}_{-}$DEATHS $_{\mathrm{a}}$. In the case of LE_BIRTH, the probabilities depend on the population at each age $\left(\mathrm{POP}_{\mathrm{a}}\right)$ as well as the number of deaths: $\mathrm{p}_{2 \mathrm{a}}=\mathrm{d}_{\mathrm{a}-1}\left[\left(1-\mathrm{d}_{0}\right)\left(1-\mathrm{d}_{1}\right) \ldots(1-\right.$ $\left.d_{a-2}\right)$ ], where $d_{a}=N_{-}$DEATHS ${ }_{a} /$ POP $_{a}$. Since the AGE_DEATH calculation is based only on people who have died, whereas the LE_BIRTH calculation is based on the entire population, AGE_DEATH might be considered a censored measure. Although LE_BIRTH can't be measured by disease, both measures (and the correlation between them) can be calculated by country and year. Both measures were calculated for 39 European countries during the period 1960-2010. Lichtenberg (2014) showed that there is a very strong positive correlation across countries between LE_BIRTH in 2010 and AGE_DEATH in 2010. The weighted (by total number of deaths) least-squares coefficient from the regression of LE_BIRTH on AGE_DEATH is 1.21 ( $\mathrm{t}$-value $=16.6, \mathrm{R}^{2}=0.88$ ). There is also a strong positive correlation across countries between the growth rates of AGE_DEATH and LE_BIRTH. ${ }^{8}$

The measure of pharmaceutical innovation in eq. (1) - the number of chemical substances previously commercialized to treat a disease - is not the theoretically ideal measure. Longevity

\footnotetext{
${ }^{7}$ Government agencies such as the Australian Institute of Health and Welfare (2013), Statistics Canada (http://www.cbc.ca/news/canada/story/2008/01/14/death-stats.html), and the

Arizona Department of Health Services (http://www.azdhs.gov/plan/report/ahs/ahs2010/pdf/2d1.pdf) publish data on mean age at death.

${ }^{8}$ In a weighted (by total number of deaths) least-squares regression of the form $\mathrm{LE}_{-} \mathrm{BIRTH}_{\mathrm{ct}}=\beta$ AGE_DEATH $\mathrm{At}_{\mathrm{ct}}+$ $\alpha_{\mathrm{c}}+\delta_{\mathrm{t}}+\varepsilon_{\mathrm{ct}}$, where LE_BIRTH $\mathrm{ct}_{\mathrm{ct}}=\mathrm{LE} \_$BIRTH in country $\mathrm{c}$ in year $\mathrm{t}$, the estimate of $\beta$ is $0.523(\mathrm{Z}=5.39$, p-value $<.0001)$.
} 
is presumably more strongly related to the drugs actually used to treat a disease than it is to the drugs that could be used to treat the disease. A preferable measure is the mean vintage of drugs used to treat a disease, defined as VINTAGE $\mathrm{Vit}_{\mathrm{d}}=\sum_{\mathrm{d}} \mathrm{Q}_{\mathrm{dit}} \mathrm{LAUNCH}_{-} \mathrm{YEAR}_{\mathrm{d}} / \sum_{\mathrm{d}} \mathrm{Q}_{\mathrm{dit}}$, where $\mathrm{Q}_{\mathrm{dit}}$ $=$ the quantity of drug $\mathrm{d}$ used to treat disease $\mathrm{i}$ in year $\mathrm{t}$, and LAUNCH_YEAR $\mathrm{L}_{\mathrm{d}}=$ the world launch year of drug d. ${ }^{9}$ Unfortunately, measurement of VINTAGE it $_{\text {in }}$ infeasible: although data on the total quantity of each drug in each year $\left(\mathrm{Q}_{\mathrm{d} . \mathrm{t}}=\Sigma_{\mathrm{i}} \mathrm{Q}_{\mathrm{dit}}\right)$ are available, many drugs are used to treat multiple diseases, and there is no way to determine the quantity of drug $\mathrm{d}$ used to treat disease $i$ in year t. ${ }^{10}$ However, Lichtenberg (2014) showed that in France there is a highly significant positive correlation across drug classes between changes in the (quantity-weighted) vintage of drugs and changes in the number of chemical substances previously commercialized within the drug class.

Pharmaceutical innovation is not the only type of medical innovation that is likely to contribute to longevity growth. Other medical innovation, such as innovation in diagnostic imaging, surgical procedures, and medical devices, is also likely to affect longevity growth. Therefore, measures of these other types of medical innovation should be included in the longevity model (eq. (1)). ${ }^{11}$ Unfortunately, longitudinal disease-level measures of nonpharmaceutical medical innovation are not available for Greece. However, longitudinal diseaselevel measures of non-pharmaceutical and pharmaceutical medical innovation are available for the U.S. during the period 1997-2007. Lichtenberg (2014) showed that, in the U.S., the rate of pharmaceutical innovation is not positively correlated with the rate of medical procedure innovation and may be negatively correlated with the rate of diagnostic imaging innovation. This suggests that failure to control for other medical innovation is unlikely to result in overestimation of the effect of pharmaceutical innovation on longevity growth.

\footnotetext{
${ }^{9}$ According to the Merriam Webster dictionary, one definition of vintage is "a period of origin or manufacture (e.g. a piano of 1845 vintage)". http://www.merriam-webster.com/dictionary/vintage. Robert Solow (1960) introduced the concept of vintage into economic analysis. Solow's basic idea was that technical progress is "built into" machines and other goods and that this must be taken into account when making empirical measurements of their roles in production. This was one of the contributions to the theory of economic growth that the Royal Swedish Academy of Sciences cited when it awarded Solow the 1987 Alfred Nobel Memorial Prize in Economic Sciences. ${ }^{10}$ Outpatient prescription drug claims usually don't show the indication of the drug prescribed. Claims for drugs administered by doctors and nurses (e.g. chemotherapy) often show the indication of the drug, but these account for just $15 \%$ of drug expenditure. These data are not available for Greece.

${ }^{11}$ However, the number of people exposed to pharmaceutical innovation tends to be much larger than the number of people exposed to other types of medical innovation. In 2007, 62\% of Americans consumed prescription drugs, while only 8\% of Americans were admitted to hospitals. (Source: Medical Expenditure Panel Survey, 2007 Full Year Consolidated Data File.)
} 
In eq. (1), mean age at death from disease $i$ in year $t$ depends on the number of chemical substances (drugs) to treat disease $\mathrm{i}$ commercialized by the end of year $\mathrm{t}-\mathrm{k}$, i.e. there is a lag of $\mathrm{k}$ years. One would expect there to be a substantial lag because (1) new drugs diffuse graduallythey won't be used widely until years after commercialization, and (2) drugs for chronic conditions (which account for most drug use) may have to be consumed for several years for their full health benefits to be realized. Eq. (1) will be estimated for different values of $\mathrm{k}$ : $\mathrm{k}=$ $1 \ldots, 10 .{ }^{12}$ The mean lag between the stock of drugs commercialized for a disease and mean age at death from the disease can be computed as follows, including only the values of $\mathrm{k}$ for which $\beta_{\mathrm{k}}$ is statistically significant: $\mathrm{LAG}_{-} \mathrm{MEAN}=\sum_{\mathrm{k}} \beta_{\mathrm{k}} \mathrm{k} / \sum_{\mathrm{k}} \beta_{\mathrm{k}}$.

The measure of pharmaceutical innovation, N_CHEM_SUBSTANCES $\mathrm{S}_{\mathrm{i}, \mathrm{t}-\mathrm{k}}=\sum_{\mathrm{d}} \mathrm{IND}_{\mathrm{di}}$ $\mathrm{APP}_{\mathrm{d}, \mathrm{t}-\mathrm{k}}$, is based on whether drug $\mathrm{d}$ had an indication for disease $\mathrm{i}$ at the end of 2011. One would prefer to base the measure on whether drug $\mathrm{d}$ had an indication for disease $\mathrm{i}$ at the end of year $t-k^{13}$

\section{B. Hospital utilization model}

To assess the impact of pharmaceutical innovation on hospital utilization, models of the following form will be estimated:

$$
\ln \left(\text { DAYS }_{i t}\right)=\beta_{\mathrm{k}} \ln \left(\mathrm{N}_{-} \text {CHEM_SUBSTANCES } \mathrm{i}_{\mathrm{i}, \mathrm{t}-\mathrm{k}}\right)+\alpha_{\mathrm{i}}+\delta_{\mathrm{t}}+\varepsilon_{\mathrm{it}}
$$

where DAYS $\mathrm{it}_{\mathrm{it}}=$ the number of hospital days for disease $\mathrm{i}$ in year $\mathrm{t}(\mathrm{t}=2000, \ldots, 2008)$. Eq. (2) will be estimated by weighted least-squares, weighting by $\Sigma_{\mathrm{t}} \mathrm{DAY} \mathrm{S}_{\mathrm{it}}$. Standard errors will be clustered within diseases.

\section{Data sources and descriptive statistics}

Data sources. Calculation of the number of chemical substances (drugs) to treat disease $\mathrm{i}$ commercialized by the end of year t-k requires data on drug launch dates and drug indications:

\footnotetext{
${ }^{12} \mathrm{~A}$ separate model is estimated for each value of $\mathrm{k}$, rather than including multiple values (N_CHEM_SUBSTANCES ${ }_{i, t-1}, N_{-}$_CHEM_SUBSTANCES ${ }_{i, t-3}, N_{-}$CHEM_SUBSTANCES ${ }_{i, t-5}, \ldots$ ) in a single model because N_CHEM_SUBSTANCES is highly serially correlated (by construction), which would result in extremely high multicollinearity if multiple values were included.)

${ }^{13}$ About one in four new molecular entities has supplemental indications.
} 


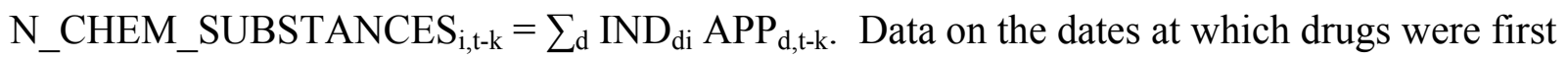
launched in Greece were obtained from the IMS LifeCycle New Product Focus database. ${ }^{14}$ Data on drug indications were obtained from Thériaque (http://www.theriaque.org/) a database of official, regulatory and bibliographic information on all drugs available in France, intended for health professionals, and funded by the Centre National Hospitalier d'Information sur le Médicament. Thériaque contains data on labeled indications, but not on off-label indications. According to the FDB MedKnowledge Indications Module, which provides a list of FDAapproved and off-label indications for a given drug, about one in four indications is off-label.

The data necessary to construct mean age at death and the number of deaths, by disease and year, were obtained from the WHO Mortality Database (http://www.who.int/healthinfo/morttables/en/), which covers deaths registered in national civil registration systems, with underlying cause of death as coded by the relevant national authority. Underlying cause of death is defined as "the disease or injury which initiated the train of morbid events leading directly to death, or the circumstances of the accident or violence which produced the fatal injury" in accordance with the rules of the International Classification of Diseases. ${ }^{15}$ Data on the number of hospital days, by disease and year, were obtained from the Greek Statistical Authority

Descriptive statistics. Figure 1 shows the number of new chemical entities (NCEs) launched in Greece in each year during the period 1990-2010. [Figure 1 near here] The average annual number of NCEs launched was 21. The number ranged from 12 in 1995 to 30 in 1999.

To illustrate the nature of the disease-specific data on pharmaceutical innovation, Table 1 shows the post-1982 drugs used to treat two types of cancer, listed in order of Greek launch year. [Table 1 near here] There were 16 drugs used to treat malignant neoplasms of digestive organs and peritoneum (ICD-10 codes C15-C26), and 30 drugs used to treat malignant neoplasms of bone, connective tissue, skin and breast (C40-C50).

Figure 2 illustrates the heterogeneity of diseases with respect to their rates of pharmaceutical innovation. [Figure 2 near here] It shows the cumulative number of post-1982 new chemical entities that had previously been launched in Greece to treat six types of cancer during the period 1995-2010. In 1995, there were nine drugs for malignant neoplasms of

\footnotetext{
${ }^{14}$ This database covers products launched worldwide since 1982. Good coverage of Greece began in 1990.

${ }^{15}$ Greek deaths are classified by ICD $9^{\text {th }}$ revision, Basic Tabulation List.
} 
genitourinary organs (C51-C63), and nine drugs for malignant neoplasms of bone, connective tissue, skin and breast (C40-C50). The number of drugs for the second disease increased by 21 , more than twice as much as the number of drugs for the first disease (by 9).

Table 2 shows data on ten of the leading causes of death in Greece: the number of deaths and mean age at death in 1995 and 2010, and the cumulative number of drugs launched three years earlier. [Table 2 near here] Table 3 shows 2008 hospital statistics, by broad disease category. [Table 3 near here]

\section{Empirical results}

\section{A. Longevity equation estimates}

Estimates of parameters from longevity (mean age at death) models are presented in Table 4. ${ }^{16}$ [Table 4 near here] All models were estimated by weighted least squares, weighting by N_DEATHS ${ }_{i t}$, the number of deaths from disease $\mathrm{i}$ in year $\mathrm{t}$. This is appropriate because, due to the inclusion of fixed disease effects, we are in essence analyzing within-disease changes in age at death and the variance of these changes is much larger for diseases causing few deaths than it is for diseases causing many deaths.

Table 4 shows estimates of $\beta_{\mathrm{k}}(\mathrm{k}=1, . ., 10)$ from eq. (1). Each estimate is from a separate model. ${ }^{17}$ The estimates of $\beta_{\mathrm{k}}$ are positive and significant for $1 \leq \mathrm{k} \leq 7$. This indicates that an increase in the number of chemical substances for a disease has a positive effect on mean age at death from the disease 1-7 years later.

As noted earlier, our estimates enable us to determine how much of the increase in mean age at death during the sample period (1995-2010) can be attributed to the introduction of new drugs. As shown in Figure 3, between 1995 and 2010, mean age at death increased by 2.0 years,

\footnotetext{
${ }^{16}$ The estimates in the paper are based on the default covariance structure of multivariate responses: independent. I obtain identical estimates when I specify the covariance structure to be exchangeable. I also estimated the model when the covariance structure was specified as first-order autoregressive. These estimates seem much less plausible than the estimates based on the independent covariance structure, because they are less consistent with a smoothness prior: the hypothesis that physical properties in a neighborhood of space or in an interval of time present some coherence and generally do not change abruptly.

${ }^{17}$ Estimates of all parameters of the model AGE_DEATH ${ }_{i t}=\beta_{3} N_{-}$CHEM_SUBSTANCES $\mathrm{i}_{\mathrm{i}, \mathrm{-}-3}+\alpha_{\mathrm{i}}+\delta_{\mathrm{t}}+\varepsilon_{\mathrm{it}}$ are shown in Appendix Table 1.
} 
from 74.7 to 76.7 . [Figure 3 near here] Estimates of eq. (1) where $k=3$ imply that, in the absence of pharmaceutical innovation, mean age at death would have increased by 1.1 years, from 74.7 to 75.8 . In other words, pharmaceutical innovation increased longevity in Greece by .87 years during the period $1995-2010-44 \%$ of the total increase.

\section{B. Hospital utilization equation estimates}

Estimates of parameters from hospital utilization models are presented in Table $5 .{ }^{18}$

[Table 5 near here] Four of the estimates (for $1 \leq k \leq 4$ ) are negative and significant ( $p$-value $<$ .06). This indicates that diseases with larger increases in the cumulative number of NCEs 1-4 years earlier had smaller increases in the number of hospital days.

As shown in Figure 4, between 2000 and 2008, the number of hospital days fell slightly, from 14.0 million to 13.9 million. [Figure 4 near here] Estimates of eq. (2) where $\mathrm{k}=4 \mathrm{imply}$ that, in the absence of pharmaceutical innovation, the number of hospital days would have increased by 2.5 million, from 14.0 million to 16.5 million. In other words, pharmaceutical innovation reduced hospital utilization at an average annual rate of $2.1 \%$.

\section{The cost-effectiveness of pharmaceutical innovation in Greece}

Now I will use estimates of the effect of pharmaceutical innovation on mean age at death (Table 4) and hospital utilization (Table 5) to calculate the incremental cost-effectiveness of pharmaceutical innovation, i.e. the cost per life year gained from the introduction of new drugs. The incremental cost-effectiveness ratio (ICER) is defined as follows: ${ }^{19}$

$$
\begin{aligned}
& \operatorname{ICER}=\left(\underline{L E}_{\text {actual }} * \operatorname{MedExpend}_{\text {actual }}\right)-\left(\mathrm{LE}_{\mathrm{no} \text { innovation }} * \operatorname{MedExpend}_{\text {no }} \text { innovation }\right) \\
& \mathrm{LE}_{\text {actual }}-\mathrm{LE}_{\mathrm{no} \_ \text {innovation }}
\end{aligned}
$$

where

$$
\text { MedExpend }_{\text {actual }}=\text { actual per capita medical expenditure in } 2007
$$

\footnotetext{
${ }^{18}$ Estimates of all parameters of the model $\ln \left(\mathrm{DAYS}_{\mathrm{it}}\right)=\beta_{4} \ln \left(\mathrm{CUM} \_\mathrm{NCE} \mathrm{E}_{\mathrm{i},-4}\right)+\alpha_{\mathrm{i}}+\delta_{\mathrm{t}}+\varepsilon_{\mathrm{it}}$ are shown in Appendix Table 2.

${ }^{19} \mathrm{LE}_{\text {actual }}$ * MedExpend $\mathrm{actual}_{1}=$ actual (undiscounted) lifetime medical expenditure; $\mathrm{LE}_{\mathrm{no} \_ \text {innovation }}$ * MedExpend $_{\text {no innovation }}=$ estimated (undiscounted) lifetime medical expenditure in the absence of 9 prior years of pharmaceutical innovation.
} 
MedExpend $_{\text {no_innovation }}=$ estimated per capita medical expenditure in 2007 in the absence of 7 prior years of pharmaceutical innovation

$$
\begin{aligned}
\mathrm{LE}_{\text {actual }} & =\text { actual life expectancy in } 2007 \\
\mathrm{LE}_{\text {no_innovation }} & =\text { estimated life expectancy in } 2007 \text { in the absence of } 7 \text { prior years of } \\
& \text { pharmaceutical innovation }
\end{aligned}
$$

Table 6 shows a "baseline" calculation of the ICER. [Table 6 near here] Line 1 shows the actual value of life expectancy (mean age at death) in 2007 (76.49 years), and the estimated value (76.04 years, derived from the estimate of $\beta_{3}$ in Table 4 ) in the absence of (lagged) pharmaceutical innovation during the period 2000-2007. The estimates indicate that life expectancy would have been 0.45 years (5.4 months) lower in 2007 in the absence of pharmaceutical innovation. Lines 2-4 show three components of medical expenditure, and line 5 shows their sum, total medical expenditure. The 2007 actual values (expressed in USD PPP) were obtained from Economou (2010) and http://stats.oecd.org/. ${ }^{20}$ Pharmaceutical expenditure is considered first, in line 2. During this period, real per capita pharmaceutical expenditure increased at an average annual rate of $11.1 \%$ (OECD Table 7.4.3). To be conservative, we will assume that pharmaceutical innovation was responsible for the entire $11.1 \%$ annual growth in real per capita pharmaceutical expenditure, i.e. it increased per capita pharmaceutical expenditure by $\$ 222$ (from $\$ 204$ to $\$ 427$ ) between 2000 and 2007 .

Hospital expenditure is considered next, in line 3. The estimate of $\beta_{4}$ in Table 5 implied that, in the absence of lagged pharmaceutical innovation during 2000-2007, the number of hospital days would have been $16.5 \%\left(=1.022^{7}-1\right)$ higher in 2007. Evidence based on U.S. data indicates that the elasticity of hospital expenditure with respect to the number of hospital days is about 0.81. If it is assumed that this also applies to Greece, then hospital expenditure would have been $12.3 \%\left(=0.81 * \ln \left(1.022^{7}\right)\right)$ higher in 2007 in the absence of lagged pharmaceutical innovation during 2000-2007. Hence, per capita hospital pharmaceutical expenditure in 2007 would have been $\$ 138$ higher (\$1191 instead of \$1053). Longitudinal disease-level data on expenditure on or utilization of other medical services are not available, so it is assumed (in line 4) that pharmaceutical innovation had no effect on other medical

\footnotetext{
${ }^{20}$ The 2007 actual values depend on the age/gender and health of the Greek population.
} 
expenditure. As shown in line 5, under these assumptions per capita medical expenditure in 2007 would have been $\$ 84$ lower in the absence of prior pharmaceutical innovation, because the estimated increase in hospital expenditure would have been smaller than the estimated reduction in pharmaceutical expenditure. Lifetime medical expenditure would have been $\$ 7702$ lower in the absence of prior pharmaceutical innovation, due to the reductions in life expectancy and annual medical expenditure. The calculations in Table 6 imply that the cost per life-year gained from the introduction of new drugs was $\$ 17,117$ ( $=-\$ 7702 /-0.45$ years), which is a very small fraction of leading economists' estimates of the value of (or consumers' willingness to pay for) a one-year increase in life expectancy. Aldy and Viscusi (2008) estimate that the average value of (willingness to pay for) an American life-year is $\$ 300,000$.

There are several good reasons to think that the calculations in Table 6 lead to an overestimate of the ICER. First, the increase in life expectancy attributable to pharmaceutical innovation may be underestimated. The increase in life expectancy at birth during 1995-2010 was $13 \%$ larger than the increase in mean age at death (2.81 years vs. 2.48 years). Second, some of the increase in pharmaceutical expenditure may be attributable to factors other than pharmaceutical innovation. And third, in Table 6 it is assumed that pharmaceutical innovation had no effect on other medical expenditure, but it may have reduced other medical expenditureespecially nursing home expenditure - as it appears to have reduced hospital expenditure.

This study is subject to several limitations. One limitation is that the estimates do not capture between-disease spillover effects, because the relationship analyzed is between pharmaceutical innovation related to a disease and the mean age of deaths caused by the disease. These effects appear to be fairly modest in practice, but accounting for these spillover effects would certainly be desirable.

A second limitation is that the outcome measure analyzed is the number of life-years, not the number of quality-adjusted life-years (QALYs). As argued in Lichtenberg (2009), even though quality of life is generally far from perfect towards the end of life, the increase in QALYs attributable to innovation could be either greater than or less than the increase in life-years.

A third limitation is that controlling for other types of medical innovation, such as innovation in diagnostic imaging, surgical procedures, and medical devices, was infeasible, since longitudinal disease-level measures of non-pharmaceutical medical innovation are not available for Greece. Such data are available for the U.S. during the period 1998-2007, and they suggest 
that failure to control for other medical innovation is unlikely to result in overestimation of the effect of pharmaceutical innovation on longevity growth, but further research on this issue is clearly warranted.

\section{Summary and conclusions}

In this paper, longitudinal, disease-level data were used to analyze the impact of pharmaceutical innovation on longevity (mean age at death), hospital utilization, and medical expenditure in Greece during the period 1995-2010. The estimates imply that pharmaceutical innovation increased mean age at death by 0.87 years during this period-about $44 \%$ of the total increase in longevity. Pharmaceutical innovation may have increased real per capita pharmaceutical expenditure by $\$ 222$ during the period $2000-2007$, but we estimate that $62 \%$ of this increase was offset by a reduction in hospital expenditure. The baseline estimate of the cost per life-year gained from pharmaceutical innovation in Greece during 2000-2007 is about $\$ 17,117$.

As shown in Figure 5, the number of new drugs launched in Greece has declined dramatically in recent years. [Figure 5 near here] During the period 2000-2007, the number of new drugs launched in Greece was $72 \%$ as high as the number of new drugs launched worldwide. During the period 2008-2013, the number of new drugs launched in Greece was only $37 \%$ as high as the number of new drugs launched worldwide. The evidence presented in this paper indicates that reduced access to new drugs would have adverse long-term effects on longevity and other aspects of health.

\section{References}

Aldy, J. E., Viscusi, W. K., 2008, Adjusting the value of a statistical life for age and cohort effects. Review of Economics and Statistics 90(3), 573-581.

Arias E., 2010. United States life tables, 2006. National vital statistics reports; vol 58 no 21. National Center for Health Statistics. Hyattsville, MD.

Australian Institute of Health and Welfare, 2013. National GRIM (General Record of Incidence of Mortality) Books, http://www.aihw.gov.au/national-grim-books/ 
Australian Productivity Commission, 2005. Impacts of Advances in Medical Technology in Australia, Research Report, Melbourne, http://www.pc.gov.au/_ data/assets/pdf_file/0003/17193/medicaltechnology.pdf

Bresnahan, T. F., Gordon, R.J., 1996. The Economics of New Goods. University of Chicago Press, Chicago.

Center for Medicare and Medicaid Services (2013), National Health Expenditure Data, http://www.cms.gov/Research-Statistics-Data-and-Systems/Statistics-Trends-andReports/NationalHealthExpendData/Downloads/tables.pdf.

Chandra, A., Gruber, J., McKnight, R., 2010. Patient Cost-Sharing and Hospitalization Offsets in the Elderly. American Economic Review 100 (1), 193-213.

DiMasi, J. A., Faden, L. B., 2011. Competitiveness in follow-on drug R\&D: a race or imitation?. Nature Reviews Drug Discovery 10, 23-27.

Dorsey, E. R., et al, 2010. Financial Anatomy of Biomedical Research, 2003 - 2008. Journal of the American Medical Association 303(2), 137-143.

Economou C. 2010. Greece: Health system review. Health Syst Transit 12(7): 1-177, xv-xvi, http://www.euro.who.int/_ data/assets/pdf_file/0004/130729/e94660.pdf

Grossman, G. M., Helpman, E., 1991. Quality Ladders in the Theory of Growth. The Review of Economic Studies 58 (1), 43-61.

Grunfeld, Y., Griliches, Z., 1960. Is Aggregation Necessarily Bad?. Review of Economics and Statistics 42 (1), 1-13.

Harris, G., Thomas, K., 2013. Low-Cost Drugs in Poor Nations Get a Lift in Indian Court. New York Times, April 1.

Hercowitz, Z., 1998. The 'embodiment' controversy: A review essay. Journal of Monetary Economics 41, 217-224.

IMS Institute for Healthcare Informatics, 2011. The Global Use of Medicines: Outlook Through 2015.

http://www.imshealth.com/deployedfiles/ims/Global/Content/Insights/IMS\%20Institute $\% 20$ for $\%$ 20Healthcare\%20Informatics/Global_Use_of_Medicines_Report.pdf

Karaca-Mandic, P., Jena, A. B., Joyce, G. F., Goldman, D. P., 2012. Out-of-Pocket Medication Costs and Use of Medications and Health Care Services Among Children With Asthma. Journal of the American Medical Association 307(12), 1284-1291.

Lichtenberg, F. R., 2003. The Effect of New Drugs on HIV Mortality in the U.S., 1987-1998. Economics and Human Biology 1, 259-266. 
Lichtenberg, F. R., 2007. The Impact of New Drugs on U.S. Longevity and Medical Expenditure, 1990-2003. American Economic Review 97 (2), 438-443.

Lichtenberg, F. R., 2009. The effect of new cancer drug approvals on the life expectancy of American cancer patients, 1978-2004. Economics of Innovation and New Technology 18 (5), $407-28$.

Lichtenberg, F. R., 2010. Pharmaceutical Price Discrimination and Social Welfare. Capitalism and Society 5(1).

Lichtenberg, F. R., 2011. The quality of medical care, behavioral risk factors, and longevity growth. International Journal of Health Care Finance and Economics 11(1), 1-34,.

Lichtenberg, F. R., 2012a. The contribution of pharmaceutical innovation to longevity growth in Germany and France, 2001-2007. PharmacoEconomics 30(3), 197-211.

Lichtenberg, F. R., 2012b. Pharmaceutical Innovation and Longevity Growth in 30 Developing and High-Income Countries, 2000-2009. Health Policy and Technology 3(1): 36-58, March.

Lichtenberg, F. R., 2013a. The Effect of Pharmaceutical Innovation on Longevity: Patient Level Evidence from the 1996-2002 Medical Expenditure Panel Survey and Linked Mortality Publicuse Files. Forum for Health Economics and Policy 16(1), 1-33.

Lichtenberg, F. R., 2013b. The impact of new (orphan) drug approvals on premature mortality from rare diseases in the U.S. and France, 1999-2007. European Journal of Health Economics 14(1), 41-56.

Lichtenberg, F. R., 2014. The impact of pharmaceutical innovation on longevity and medical expenditure in France, 2000-2009. Economics and Human Biology 13: 107-127.

Lichtenberg, F. R., Duflos, G., 2008. Pharmaceutical innovation and the longevity of Australians: a first look. Advances in Health Economics and Health Services Research 19, 95117.

Lichtenberg, F. R., Grootendorst, P., Van Audenrode, M., Latremouille-Viau, D., Lefebvre, P., 2009. The impact of drug vintage on patient survival: a patient-level analysis using Quebec's provincial health plan data. Value in Health 12 (6), 847-856.

Murphy, K. M., Topel, R. H., 2006. The Value of Health and Longevity. Journal of Political Economy 114 (4), 871-904.

National Science Foundation, 2013. U.S. Corporate R\&D: Volume 1: Top 500 Firms in R\&D by Industry Category, http://www.nsf.gov/statistics/nsf00301/expendit.htm\#intensity, accessed 26 January 2013

Newhouse, J. P., 1992. Medical care costs: how much welfare loss?. Journal of Economic Perspectives 6(3), 3-21. 
Nordhaus, W. D., 2003. The Health of Nations: The Contribution of Improved Health to Living Standards, in: Murphy, K. M., Topel, R. H., Measuring the Gains from Medical Research: An Economic Approach, University of Chicago Press, Chicago.

Romer, P., 1990. Endogenous Technological Change. Journal of Political Economy 98 (5, Part 2), S71-S102.

Sampat, B. N., Lichtenberg, F. R., 2011. What are the Respective Roles of the Public and Private Sectors in Pharmaceutical Innovation? Health Affairs 30(2), 332-9.

Solow, R. M., 1960. Investment and technological progress, in: Arrow, K., Karlin, S., Suppes, P. (eds.), Mathematical Methods in Social Sciences 1959, Stanford University Press, 89-104.

World Health Organization, 2013. World Health Organization Assesses the World's Health Systems, http://www.who.int/whr/2000/media_centre/press_release/en/ 


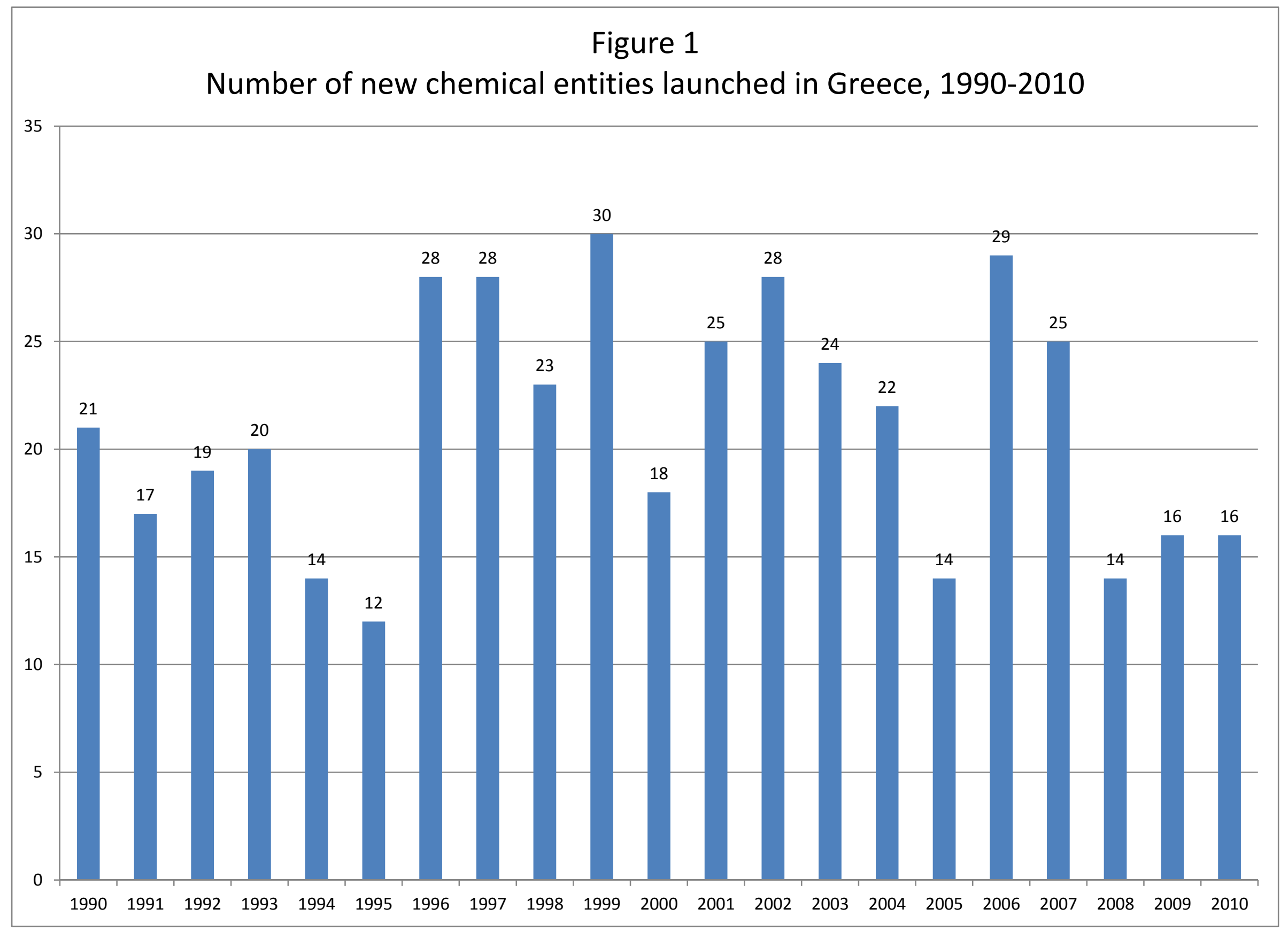




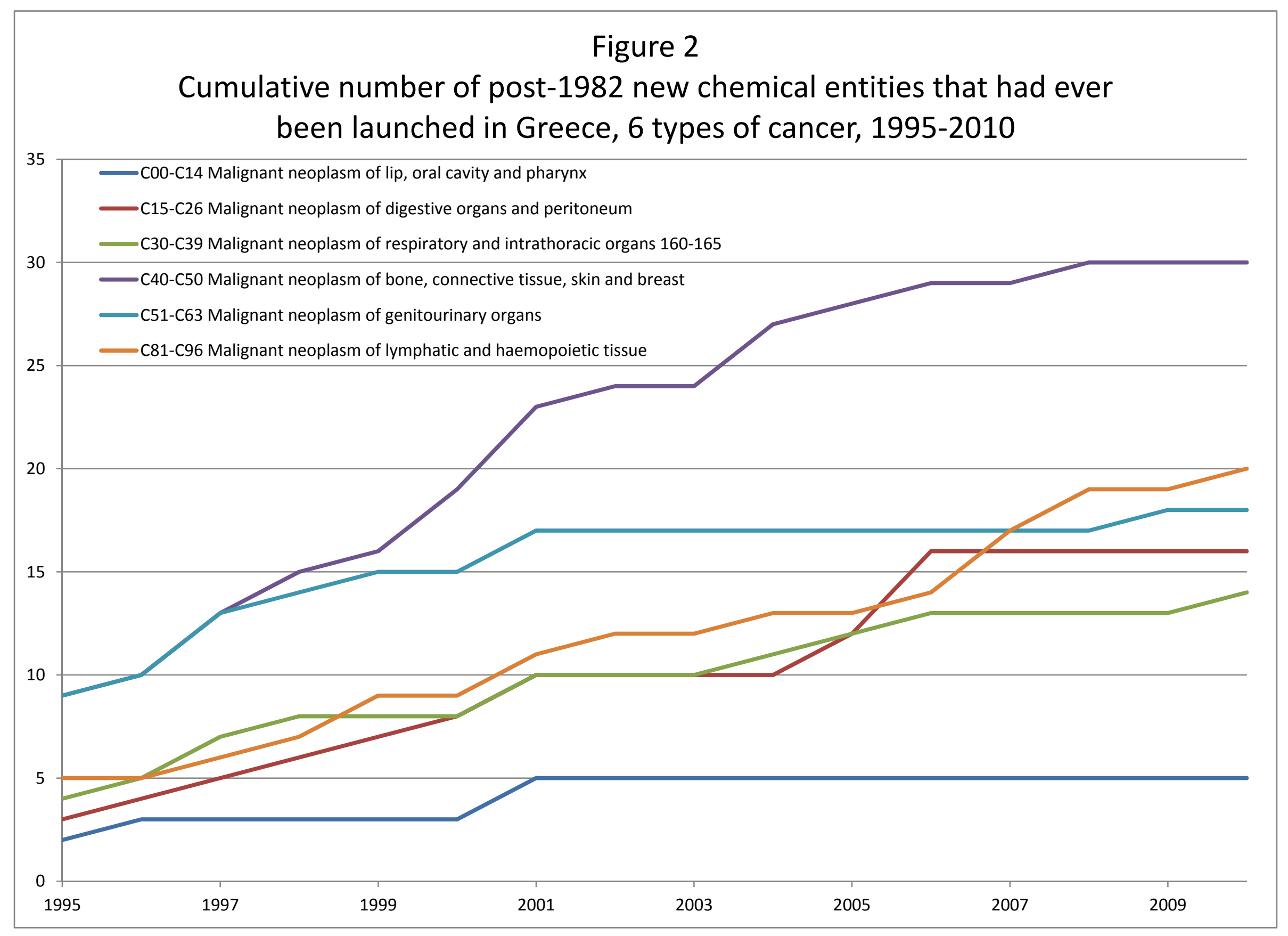




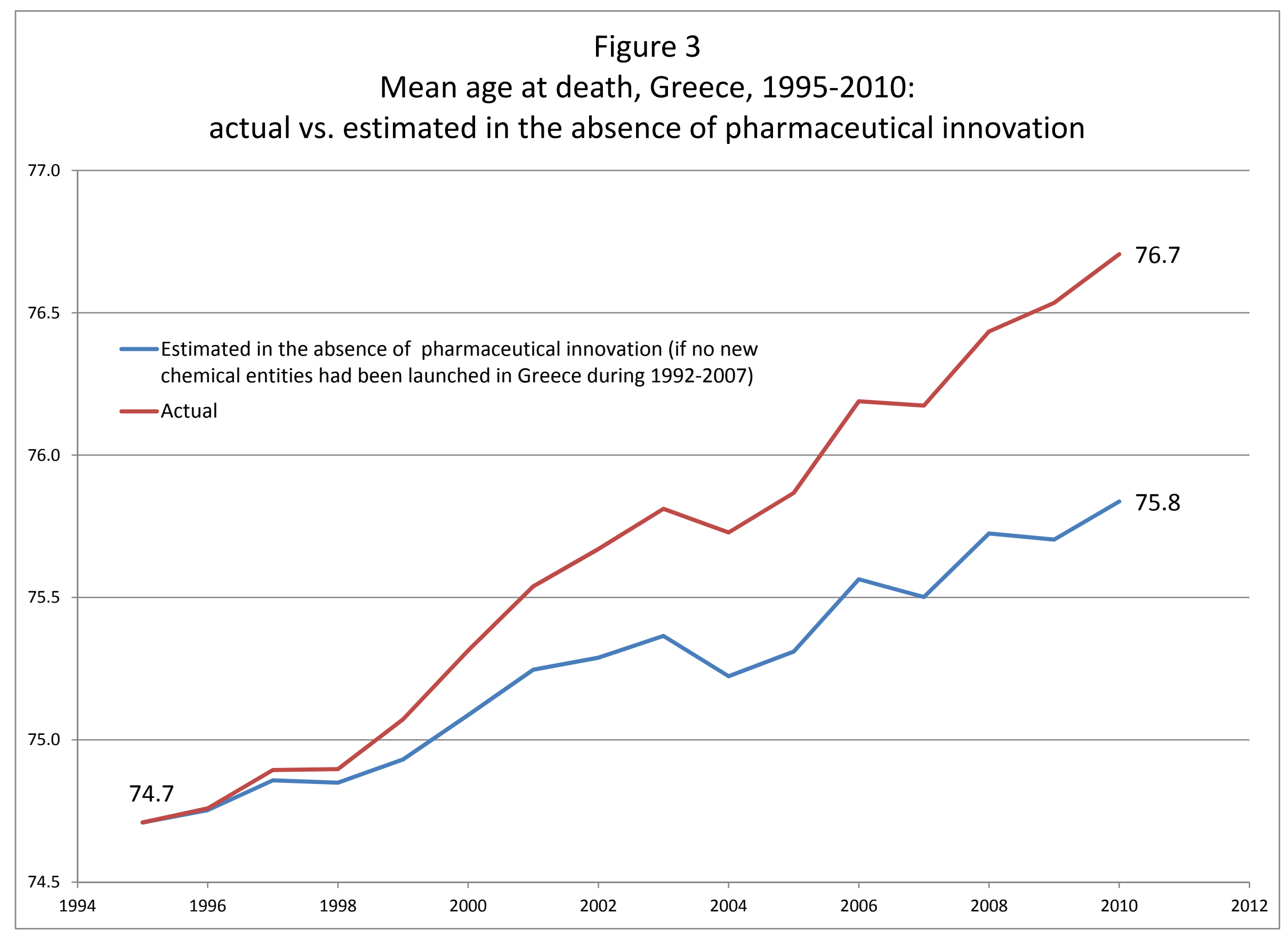




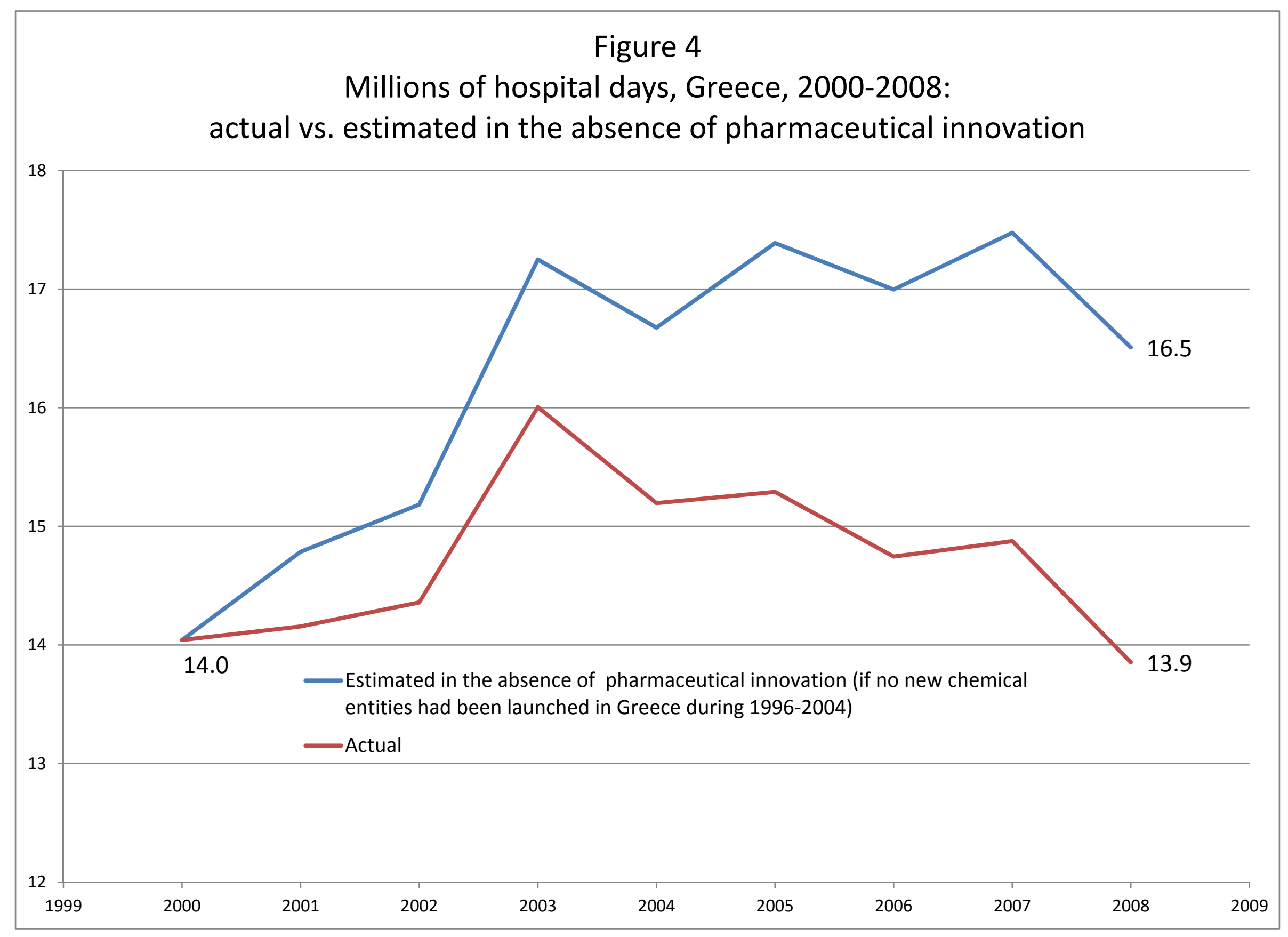




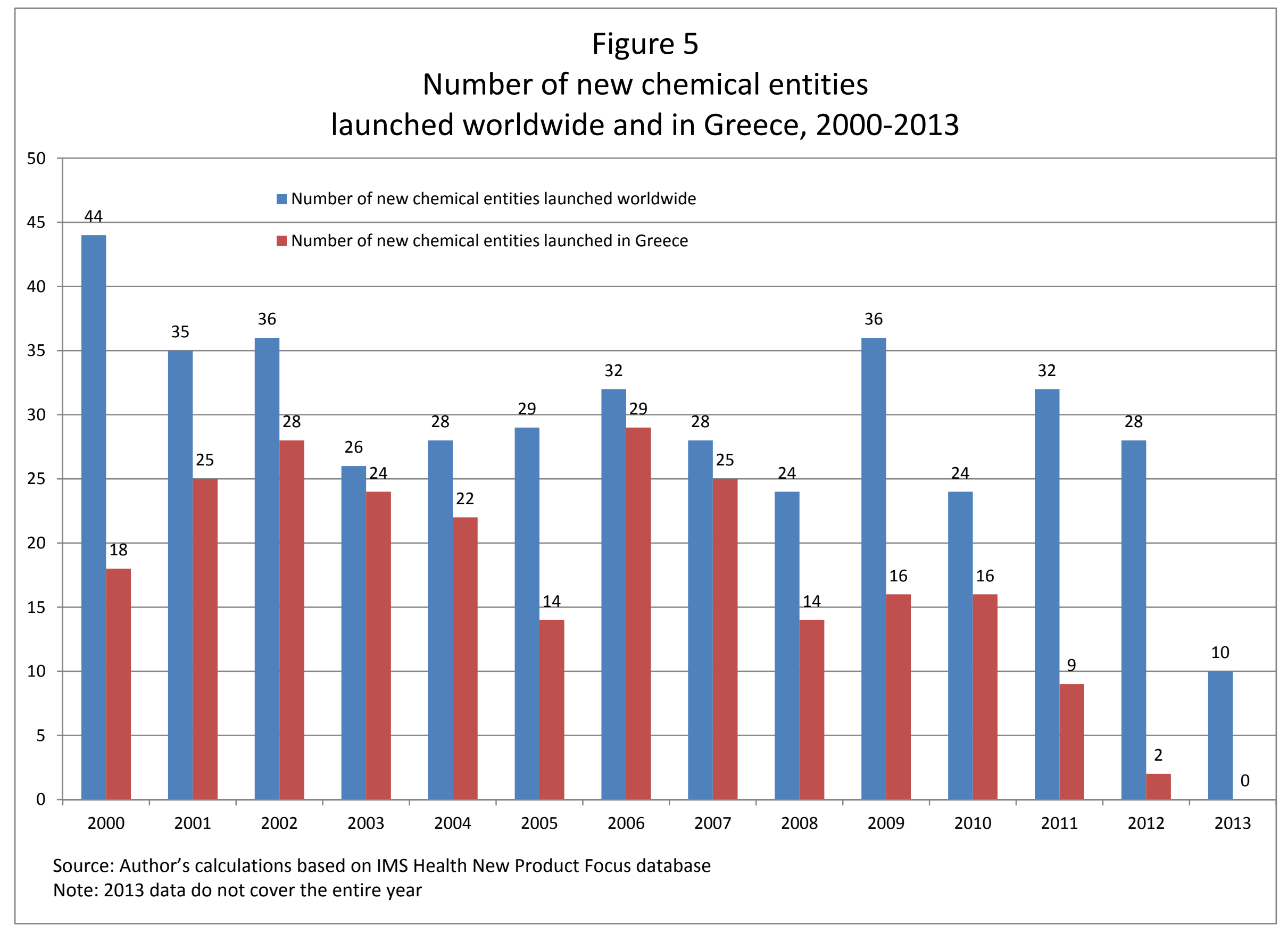


Table 1

Drugs used to treat two types of cancer, listed in order of Greek launch year

\begin{tabular}{|l|c|c|}
\hline \multicolumn{1}{|c|}{ C15-C26 Malignant neoplasm of digestive organs and peritoneum } \\
\hline \multicolumn{1}{|c|}{ Drug } & World launch year & Greek launch year \\
\hline L01DB03 Epirubicin & 1984 & 1985 \\
\hline H01CB02 Octreotide & 1988 & 1990 \\
\hline J02AC01 Fluconazole & 1988 & 1991 \\
\hline L01CD02 Docetaxel & 1995 & 1996 \\
\hline L01BC05 Gemcitabine & 1995 & 1997 \\
\hline L01XX19 Irinotecan & 1994 & 1998 \\
\hline L01BC06 Capecitabine & 1998 & 1999 \\
\hline L01XC03 Trastuzumab & 1998 & 2000 \\
\hline B03XA02 Darbepoetin alfa & 2001 & 2001 \\
\hline M05BA08 Zoledronic acid & 2000 & 2001 \\
\hline L01XA03 Oxaliplatin & 1996 & 2005 \\
\hline L01XC07 Bevacizumab & 2004 & 2005 \\
\hline L01XC06 Cetuximab & 2003 & 2006 \\
\hline L01XE03 Erlotinib & 2004 & 2006 \\
\hline L01XE04 Sunitinib & 2006 & 2006 \\
\hline L01XE05 Sorafenib & 2005 & 2006 \\
\hline
\end{tabular}

\begin{tabular}{|c|c|c|}
\hline \multicolumn{3}{|c|}{ C40-C50 Malignant neoplasm of bone, connective tissue, skin and breast } \\
\hline Drug & World launch year & Greek launch year \\
\hline L01DB03 Epirubicin & 1984 & 1985 \\
\hline L01DB07 Mitoxantrone & 1984 & 1987 \\
\hline L03AB05 Interferon alfa-2b & 1985 & 1988 \\
\hline L02AE02 Leuprorelin & 1984 & 1990 \\
\hline L03AB04 Interferon alfa-2a & 1986 & 1990 \\
\hline J02AC01 Fluconazole & 1988 & 1991 \\
\hline L02AE03 Goserelin & 1987 & 1991 \\
\hline L01CD01 Paclitaxel & 1992 & 1994 \\
\hline L02BG02 Formestane & 1993 & 1995 \\
\hline L01CD02 Docetaxel & 1995 & 1996 \\
\hline L01BC05 Gemcitabine & 1995 & 1997 \\
\hline L01CA04 Vinorelbine & 1989 & 1997 \\
\hline L02BA02 Toremifene & 1989 & 1997 \\
\hline L02BG03 Anastrozole & 1995 & 1998 \\
\hline L02BG04 Letrozole & 1996 & 1998 \\
\hline L01BC06 Capecitabine & 1998 & 1999 \\
\hline L01AD05 Fotemustine & 1989 & 2000 \\
\hline L01XC03 Trastuzumab & 1998 & 2000 \\
\hline M05BA06 Ibandronic acid & 1996 & 2000 \\
\hline B03XA02 Darbepoetin alfa & 2001 & 2001 \\
\hline D06BB10 Imiquimod & 1997 & 2001 \\
\hline L02BG06 Exemestane & 1999 & 2001 \\
\hline M05BA08 Zoledronic acid & 2000 & 2001 \\
\hline L01XE01 Imatinib & 2001 & 2002 \\
\hline L01BA04 Pemetrexed & 2004 & 2004 \\
\hline L01XX22 Alitretinoin & 1999 & 2004 \\
\hline L02BA03 Fulvestrant & 2002 & 2004 \\
\hline \begin{tabular}{|l} 
L01XC07 Bevacizumab \\
\end{tabular} & 2004 & 2005 \\
\hline L01XC06 Cetuximab & 2003 & 2006 \\
\hline L01XE07 Lapatinib & 2007 & 2008 \\
\hline
\end{tabular}


Table 2

Data on ten of the leading causes of death in Greece

\begin{tabular}{|l|c|c|c|c|c|c|}
\hline & \multicolumn{2}{|c|}{ Number of deaths } & \multicolumn{2}{c|}{ Mean age at death } & \multicolumn{2}{c|}{ Cumulative NCEs } \\
\hline Year & $\mathbf{1 9 9 5}$ & $\mathbf{2 0 1 0}$ & $\mathbf{1 9 9 5 . 0}$ & $\mathbf{2 0 1 0 . 0}$ & $\mathbf{1 9 9 2}$ & $\mathbf{2 0 0 7}$ \\
\hline Cause of death & & & & & & \\
\hline I60-I69 Cerebrovascular disease & 19,024 & 14,910 & 80.5 & 82.0 & 2 & 6 \\
\hline $\begin{array}{l}\text { I26-I52 Diseases of pulmonary } \\
\text { circulation and other forms of heart } \\
\text { disease }\end{array}$ & 17,344 & 18,936 & 81.4 & 83.1 & 10 & 28 \\
\hline $\begin{array}{l}\text { I20-I25 Ischaemic heart disease } \\
\text { C15-C26 Malignant neoplasm of } \\
\text { digestive organs and peritoneum }\end{array}$ & 12,686 & 11,332 & 73.5 & 74.0 & 8 & 21 \\
\hline $\begin{array}{l}\text { C30-C39 Malignant neoplasm of } \\
\text { respiratory and intrathoracic organs 160- } \\
\text { 165 }\end{array}$ & 5,556 & 6,799 & 68.5 & 71.0 & 3 & 16 \\
\hline $\begin{array}{l}\text { J20-J22,J40-J99 Other diseases of the } \\
\text { respiratory system }\end{array}$ & 4,762 & 7,053 & 78.6 & 80.4 & 11 & 23 \\
\hline $\begin{array}{l}\text { C51-C63 Malignant neoplasm of } \\
\text { genitourinary organs }\end{array}$ & 3,271 & 4,346 & 73.9 & 76.3 & 8 & 17 \\
\hline $\begin{array}{l}\text { K20-K93 Diseases of other parts of the } \\
\text { digestive system }\end{array}$ & 2,538 & 2,576 & 73.8 & 74.6 & 7 & 23 \\
\hline $\begin{array}{l}\text { C40-C50 Malignant neoplasm of bone, } \\
\text { connective tissue, skin and breast }\end{array}$ & 2,118 & 2,731 & 67.2 & 71.2 & 7 & 29 \\
\hline $\begin{array}{l}\text { C81-C96 Malignant neoplasm of } \\
\text { lymphatic and haemopoietic tissue }\end{array}$ & 1,658 & 1,946 & 67.9 & 72.8 & 5 & 17 \\
\hline
\end{tabular}


Table 3

2008 hospital statistics

\begin{tabular}{|c|c|c|c|}
\hline Categories of diseases & $\begin{array}{c}\text { Total patients } \\
\text { discharged }\end{array}$ & $\begin{array}{c}\text { Average } \\
\text { number of days } \\
\text { of treatment } \\
\text { per patient }\end{array}$ & $\begin{array}{c}\text { Total number } \\
\text { of days of } \\
\text { treatment }\end{array}$ \\
\hline 1. Infectious and parasitic diseases & 58,118 & 5 & 290,590 \\
\hline 2. Neoplasms & 244,365 & 7 & $1,710,555$ \\
\hline $\begin{array}{l}\text { 3. Endocrine and metabolic diseases, nutritional } \\
\text { deficiencies,immunity disorders }\end{array}$ & 48,547 & 5 & 242,735 \\
\hline 4. Diseases of blood and blood-forming organs & 35,087 & 6 & 210,522 \\
\hline 5. Mental disorders & 39,840 & 76 & $3,027,840$ \\
\hline 6. Diseases of the nervous system and sense organs & 214,319 & 3 & 642,957 \\
\hline 7. Diseases of the circulatory system & 308,033 & 6 & $1,848,198$ \\
\hline 8. Diseases of the respiratory system & 163,786 & 5 & 818,930 \\
\hline 9.Diseases of the digestive system & 223,864 & 5 & $1,119,320$ \\
\hline 10. Diseases of genito-urinary system & 173,658 & 5 & 868,290 \\
\hline $\begin{array}{l}\text { 11. Complications of pregnancy,childbirth and the } \\
\text { puerperium }\end{array}$ & 165,055 & 4 & 660,220 \\
\hline 12. Diseases of skin and subcutaneous tissue & 43,226 & 4 & 172,904 \\
\hline $\begin{array}{l}\text { 13. Diseases of the musculoskeletal system and } \\
\text { connective tissue }\end{array}$ & 97,115 & 6 & 582,690 \\
\hline 14. Congenital anomalies & 13,504 & 7 & 94,528 \\
\hline $\begin{array}{l}\text { 15.Certain conditions originating in the perinatal } \\
\text { period }\end{array}$ & 30,276 & 9 & 272,484 \\
\hline 16. Symptoms, signs and ill-defined conditions & 190,522 & 4 & 762,088 \\
\hline 17. Injury and poisoning & 171,810 & 6 & $1,030,860$ \\
\hline Grand total & $2,221,125$ & 7 & $15,547,875$ \\
\hline
\end{tabular}


Table 4

Weighted least-squares estimates of $\beta_{\mathrm{k}}$ from the model

AGE_DEATH $H_{i t}=\beta_{\mathrm{k}}$ N_CHEM_SUBSTANCES $\mathrm{i}_{\mathrm{i}, \mathrm{t}-\mathrm{k}}+\alpha_{\mathrm{i}}+\delta_{\mathrm{t}}+\varepsilon_{\mathrm{it}}$ each estimate is from a separate model weight $=\Sigma_{\mathrm{t}}$ N_DEATHS disturbances are clustered within diseases

\begin{tabular}{|l|c|c|c|c|c|c|}
\hline Parameter & Estimate & $\begin{array}{c}\text { Empirical } \\
\text { Standard } \\
\text { Error Estimates }\end{array}$ & $\begin{array}{c}\text { 95\% Lower } \\
\text { Confidence } \\
\text { Limit }\end{array}$ & $\begin{array}{c}\text { 95\% Upper } \\
\text { Confidence } \\
\text { Limit }\end{array}$ & Z & Pr > |Z| \\
\hline$\beta_{1}$ & 0.0600 & 0.0273 & 0.0066 & 0.1135 & 2.20 & 0.0278 \\
\hline$\beta_{2}$ & 0.0630 & 0.0265 & 0.0112 & 0.1149 & 2.38 & 0.0172 \\
\hline$\beta_{3}$ & 0.0669 & 0.0246 & 0.0188 & 0.1151 & 2.72 & 0.0065 \\
\hline$\beta_{4}$ & 0.0704 & 0.0264 & 0.0187 & 0.1222 & 2.67 & 0.0077 \\
\hline$\beta_{5}$ & 0.0722 & 0.0274 & 0.0186 & 0.1259 & 2.64 & 0.0084 \\
\hline$\beta_{6}$ & 0.0716 & 0.0279 & 0.0169 & 0.1263 & 2.57 & 0.0103 \\
\hline$\beta_{7}$ & 0.0634 & 0.0292 & 0.0061 & 0.1206 & 2.17 & 0.0302 \\
\hline$\beta_{8}$ & 0.0508 & 0.0295 & -0.007 & 0.1085 & 1.72 & 0.0848 \\
\hline$\beta_{9}$ & 0.0401 & 0.0324 & -0.0233 & 0.1036 & 1.24 & 0.2152 \\
\hline$\beta_{10}$ & 0.0343 & 0.0336 & -0.0316 & 0.1002 & 1.02 & 0.3077 \\
\hline
\end{tabular}

AGE_DEATH $\mathrm{it}_{\mathrm{it}}=$ mean age at death from disease $\mathrm{i}$ in year $\mathrm{t}$ N_CHEM_SUBSTANCES $S_{\mathrm{i}, \mathrm{t}-\mathrm{k}}=$ the number of chemical substances (drugs) to treat disease i commercialized in Greece by the end of year $\mathrm{t}-\mathrm{k}$ N_DEATHS ${ }_{i t}=$ the number of deaths caused by disease $i$ in year $t$ 
Table 5

Weighted least-squares estimates of $\beta_{\mathrm{k}}$ from the model

$$
\begin{aligned}
& \ln \left(\text { DAYS }_{\mathrm{it}}\right)=\beta_{\mathrm{k}} \ln \left(\mathrm{N}_{-} \text {CHEM_SUBSTANCES } \mathrm{i}_{\mathrm{i}, \mathrm{k}}\right)+\alpha_{\mathrm{i}}+\delta_{\mathrm{t}}+\varepsilon_{\mathrm{it}} \\
& \text { each estimate is from a separate model } \\
& \text { weight }=\Sigma_{\mathrm{t}} \mathrm{DAYS}_{\text {it }}
\end{aligned}
$$

disturbances are clustered within diseases

\begin{tabular}{|l|c|c|c|c|c|c|}
\hline Parameter & Estimate & $\begin{array}{c}\text { Empirical } \\
\text { Standard } \\
\text { Error Estimates }\end{array}$ & $\begin{array}{c}95 \% \text { Lower } \\
\text { Confidence } \\
\text { Limit }\end{array}$ & $\begin{array}{c}95 \% \text { Upper } \\
\text { Confidence } \\
\text { Limit }\end{array}$ & $\mathbf{Z}$ & $\operatorname{Pr}>|\mathbf{Z}|$ \\
\hline$\beta_{1}$ & -0.1411 & 0.0396 & -0.2187 & -0.0636 & -3.57 & 0.0004 \\
\hline$\beta_{2}$ & -0.1364 & 0.0600 & -0.2540 & -0.0188 & -2.27 & 0.023 \\
\hline$\beta_{3}$ & -0.1811 & 0.0950 & -0.3673 & 0.0052 & -1.91 & 0.0567 \\
\hline$\beta_{4}$ & -0.2198 & 0.1019 & -0.4194 & -0.0201 & -2.16 & 0.031 \\
\hline$\beta_{5}$ & -0.1102 & 0.0774 & -0.2620 & 0.0415 & -1.42 & 0.1545 \\
\hline$\beta_{6}$ & -0.0061 & 0.0479 & -0.1000 & 0.0879 & -0.13 & 0.8994 \\
\hline$\beta_{7}$ & -0.0481 & 0.0474 & -0.1411 & 0.0449 & -1.01 & 0.3109 \\
\hline$\beta_{8}$ & -0.0709 & 0.0445 & -0.1582 & 0.0163 & -1.59 & 0.1109 \\
\hline$\beta_{9}$ & -0.0939 & 0.0695 & -0.2302 & 0.0424 & -1.35 & 0.177 \\
\hline$\beta_{10}$ & -0.0438 & 0.0575 & -0.1565 & 0.0690 & -0.76 & 0.4468 \\
\hline
\end{tabular}

$\mathrm{DAYS}_{i \mathrm{t}}=$ the number of hospital days for disease $\mathrm{i}$ in year $\mathrm{t}$

N_CHEM_SUBSTANCES $\mathrm{S}_{\mathrm{i}, \mathrm{t}-\mathrm{k}}=$ the number of chemical substances (drugs) to treat disease i commercialized in Greece by the end of year $t-k$ 
Table 6

Baseline estimate of cost per life-year gained from pharmaceutical innovation

\begin{tabular}{|c|c|c|c|c|}
\hline Line & Variable & $\begin{array}{c}\text { Actual values, } \\
2007\left(Y_{\text {actual }}\right)\end{array}$ & $\begin{array}{l}\text { Estimated values in } \\
2007 \text { in the absence of } \\
7 \text { prior years of } \\
\text { pharmaceutical } \\
\left.\text { innovation ( } Y_{\text {no_innovation }}\right)\end{array}$ & $\begin{array}{c}\text { Difference } \\
\left(Y_{\text {no_innovation }}-Y_{\text {actual }}\right)\end{array}$ \\
\hline \multirow[t]{2}{*}{1} & $\begin{array}{c}\text { Life expectancy (Mean } \\
\text { age at death) }\end{array}$ & $76.49^{a}$ & 76.04 & -0.45 \\
\hline & $\frac{\frac{\text { Per capita medical }}{\text { expenditure in 2007, USD }}}{\text { PPP }}$ & & & \\
\hline 2 & $\begin{array}{c}\text { Prescription drug } \\
\text { expenditure }\end{array}$ & $\$ 427^{b}$ & $204^{c}$ & $-\$ 222$ \\
\hline 3 & Hospital expenditure & $\$ 1,053^{b}$ & $\$ 1,191$ & $\$ 138$ \\
\hline 4 & $\begin{array}{l}\text { Other medical } \\
\text { expenditure }\end{array}$ & $\$ 1,244$ & $\$ 1,244$ & $\$ 0$ \\
\hline 5 & Total medical expenditure & $\$ 2,724^{d}$ & $\$ 2,639$ & $-\$ 84$ \\
\hline 6 & $\begin{array}{c}\text { Lifetime medical } \\
\text { expenditure (= life } \\
\text { expectancy } * \text { total } \\
\text { medical expenditure in } \\
\text { 2007) }\end{array}$ & $\$ 208,372$ & $\$ 200,670$ & $-\$ 7,702$ \\
\hline
\end{tabular}

a. WHO Mortality Database

b. Tables 3.2 and 3.4, Economou C. (2010) Greece: Health system review. Health Syst Transit 12(7): 1177, xv-xvi, http://www.euro.who.int/_data/assets/pdf_file/0004/130729/e94660.pdf

c. Estimate based on assumption that pharmaceutical innovation was responsible for the entire $11.1 \%$ (OECD Table 7.4.3) annual growth in real per capita pharmaceutical expenditure d. OECD Table 7.1.1 
Appendix Table 1

Estimates of all parameters of the model AGE_DEATH $\mathrm{it}_{\mathrm{it}}=\beta_{3} \mathrm{~N}_{-}$CHEM_SUBSTANCES $\mathrm{i}_{\mathrm{i}, \mathrm{-}-3}+\alpha_{\mathrm{i}}+\delta_{\mathrm{t}}+\varepsilon_{\mathrm{it}}$

\begin{tabular}{|c|c|c|c|c|c|}
\hline Parameter & Level1 & Estimate & Standard Error & $\mathbf{Z}$ & $\operatorname{Pr}>|Z|$ \\
\hline cum_nce3 & & 0.0669 & 0.0246 & 2.72 & 0.0065 \\
\hline Year & 1995 & -1.1273 & 0.3715 & -3.03 & 0.0024 \\
\hline Year & 1996 & -1.0838 & 0.3759 & -2.88 & 0.0039 \\
\hline Year & 1997 & -0.9795 & 0.3491 & -2.81 & 0.005 \\
\hline Year & 1998 & -0.9875 & 0.2746 & -3.6 & 0.0003 \\
\hline Year & 1999 & -0.9059 & 0.2912 & -3.11 & 0.0019 \\
\hline Year & 2000 & -0.75 & 0.2905 & -2.58 & 0.0098 \\
\hline Year & 2001 & -0.5906 & 0.2661 & -2.22 & 0.0265 \\
\hline Year & 2002 & -0.5484 & 0.2131 & -2.57 & 0.0101 \\
\hline Year & 2003 & -0.472 & 0.196 & -2.41 & 0.016 \\
\hline Year & 2004 & -0.6136 & 0.1569 & -3.91 & $<.0001$ \\
\hline Year & 2005 & -0.5272 & 0.1499 & -3.52 & 0.0004 \\
\hline Year & 2006 & -0.2729 & 0.146 & -1.87 & 0.0617 \\
\hline Year & 2007 & -0.3356 & 0.0831 & -4.04 & $<.0001$ \\
\hline Year & 2008 & -0.1123 & 0.1164 & -0.96 & \begin{tabular}{|l|}
0.3347 \\
\end{tabular} \\
\hline Year & 2009 & -0.1336 & 0.0698 & -1.91 & 0.0558 \\
\hline Year & 2010 & 0 & 0 & . & 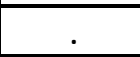 \\
\hline Cause & A00-A09 Intestinal infectious diseases & 7.3743 & 0.2779 & 26.54 & $<.0001$ \\
\hline Cause & A15-A19 Tuberculosis & 15.6621 & 0.3192 & 49.07 & $<.0001$ \\
\hline Cause & A20-A79 Other bacterial diseases & 20.1831 & 0.0632 & 319.36 & $<.0001$ \\
\hline Cause & A80-B34 Viral diseases & 5.3896 & 0.0717 & 75.2 & $<.0001$ \\
\hline Cause & $\begin{array}{l}\text { C00-C14 Malignant neoplasm of lip, oral } \\
\text { cavity and pharynx }\end{array}$ & 12.3417 & 0.2557 & 48.27 & $<.0001$ \\
\hline Cause & $\begin{array}{l}\text { C15-C26 Malignant neoplasm of digestive } \\
\text { organs and peritoneum }\end{array}$ & 16.9134 & 0.1493 & 113.32 & $<.0001$ \\
\hline Cause & $\begin{array}{l}\text { C30-C39 Malignant neoplasm of respiratory } \\
\text { and intrathoracic organs } 160-165\end{array}$ & 13.1754 & 0.1461 & 90.17 & $<.0001$ \\
\hline Cause & $\begin{array}{l}\text { C40-C50 Malignant neoplasm of bone, } \\
\text { connective tissue, skin and breast }\end{array}$ & 12.0989 & 0.1211 & 99.88 & $<.0001$ \\
\hline Cause & $\begin{array}{l}\text { C51-C63 Malignant neoplasm of } \\
\text { genitourinary organs }\end{array}$ & 18.2847 & 0.0433 & 422.4 & $<.0001$ \\
\hline Cause & $\begin{array}{l}\text { C81-C96 Malignant neoplasm of lymphatic } \\
\text { and haemopoietic tissue }\end{array}$ & 14.4887 & 0.1183 & 122.47 & $<.0001$ \\
\hline Cause & D00-D09 Carcinoma in situ & 17.1639 & 0.2283 & 75.2 & $<.0001$ \\
\hline Cause & D10-D36 Benign neoplasm & 14.4894 & 0.2219 & 65.3 & $<.0001$ \\
\hline Cause & $\begin{array}{l}\text { D50-D89 Diseases of blood and blood- } \\
\text { forming organs }\end{array}$ & 9.9988 & 0.1357 & 73.67 & $<.0001$ \\
\hline
\end{tabular}




\begin{tabular}{|c|c|c|c|c|c|}
\hline Cause & $\begin{array}{l}\text { E00-E35,E70-E90 Endocrine and metabolic } \\
\text { diseases, immunity disorders }\end{array}$ & 15.4685 & 0.4612 & 33.54 & $<.0001$ \\
\hline Cause & E40-E68 Nutritional deficiencies & 0.1183 & 0.2625 & 0.45 & 0.6522 \\
\hline Cause & F00-F99 Mental disorders & 17.953 & 0.1003 & 179.04 & $<.0001$ \\
\hline Cause & G00-G99 Diseases of the nervous system & 11.6561 & 0.3364 & 34.65 & $<.0001$ \\
\hline Cause & H00-H59 Disorders of the eye and adnexa & 2.9784 & 0.0873 & 34.13 & $<.0001$ \\
\hline Cause & $\begin{array}{l}\text { H60-H95 Diseases of the ear and mastoid } \\
\text { process }\end{array}$ & 11.4428 & 0.1542 & 74.22 & $<.0001$ \\
\hline Cause & $\begin{array}{l}\text { I00-109 Rheumatic fever and rheumatic } \\
\text { heart disease }\end{array}$ & 15.1964 & 0.2801 & 54.25 & $<.0001$ \\
\hline Cause & I10-I15 Hypertensive disease & 22.9013 & 0.2442 & 93.79 & $<.0001$ \\
\hline Cause & I20-I25 Ischaemic heart disease & 16.701 & 0.0327 & 510.96 & $<.0001$ \\
\hline Cause & $\begin{array}{l}\text { 126-I52 Diseases of pulmonary circulation } \\
\text { and other forms of heart disease }\end{array}$ & 24.9027 & 0.1066 & 233.67 & $<.0001$ \\
\hline Cause & 160-I69 Cerebrovascular disease & 24.7121 & 0.2387 & 103.54 & $<.0001$ \\
\hline Cause & $\begin{array}{l}\text { 170-199 Other diseases of the circulatory } \\
\text { system }\end{array}$ & 18.8488 & 0.2242 & 84.06 & $<.0001$ \\
\hline Cause & $\begin{array}{l}\text { J00-J18,J30-J39 Diseases of the upper } \\
\text { respiratory tract }\end{array}$ & 23.1765 & 0.2196 & 105.53 & $<.0001$ \\
\hline Cause & $\begin{array}{l}\text { J20-J22,J40-J99 Other diseases of the } \\
\text { respiratory system }\end{array}$ & 21.9118 & 0.096 & 228.13 & $<.0001$ \\
\hline Cause & $\begin{array}{l}\text { K00-K14 Diseases of oral cavity, salivary } \\
\text { glands and jaws }\end{array}$ & 17.3414 & 0.2983 & 58.14 & $<.0001$ \\
\hline Cause & $\begin{array}{l}\text { K20-K93 Diseases of other parts of the } \\
\text { digestive system }\end{array}$ & 16.7264 & 0.0547 & 305.54 & $<.0001$ \\
\hline Cause & N00-N39 Diseases of urinary system & 21.3178 & 0.1658 & 128.56 & $<.0001$ \\
\hline Cause & N40-N51 Diseases of male genital organs & 15.6726 & 0.0631 & 248.54 & $<.0001$ \\
\hline Cause & N60-N99 Diseases of female genital organs & 0 & 0 & . & \\
\hline Intercept & & 56.7021 & 0.4977 & 113.94 & $<.0001$ \\
\hline
\end{tabular}


Appendix Table 2

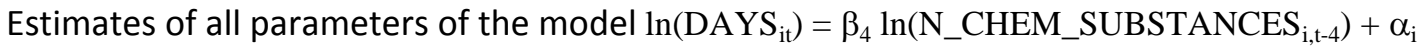

$$
+\delta_{\mathrm{t}}+\varepsilon_{\mathrm{it}}
$$

\begin{tabular}{|c|c|c|c|c|c|}
\hline Parameter & Level1 & Estimate & Standard Error & $\mathbf{Z}$ & $\operatorname{Pr}>|Z|$ \\
\hline Icum_nce4 & & -0.2198 & 0.1019 & -2.16 & 0.031 \\
\hline year & 2000 & -0.1619 & 0.0811 & -2 & 0.0458 \\
\hline year & 2001 & -0.1103 & 0.0854 & -1.29 & 0.1962 \\
\hline year & 2002 & -0.0837 & 0.08 & -1.05 & 0.2952 \\
\hline year & 2003 & 0.0439 & 0.0583 & 0.75 & 0.4516 \\
\hline year & 2004 & 0.01 & 0.0484 & 0.21 & 0.8364 \\
\hline year & 2005 & 0.0519 & 0.0495 & 1.05 & 0.2944 \\
\hline year & 2006 & 0.0291 & 0.0516 & 0.56 & 0.5722 \\
\hline year & 2007 & 0.0569 & 0.0329 & 1.73 & 0.0843 \\
\hline year & 2008 & 0 & 0 & & . \\
\hline group & $\mathrm{A} 00$ & 1.0456 & 0.0215 & 48.55 & $<.0001$ \\
\hline group & A15 & -0.0249 & 0.0167 & -1.49 & 0.1355 \\
\hline group & A20 & -1.7136 & 0.1134 & -15.11 & $<.0001$ \\
\hline group & A30 & 1.2693 & 0.2531 & 5.02 & $<.0001$ \\
\hline group & A50 & -2.1005 & 0.2369 & -8.87 & $<.0001$ \\
\hline group & A65 & -3.7693 & 0.0215 & -175 & $<.0001$ \\
\hline group & B20 & -1.2543 & 0.1909 & -6.57 & $<.0001$ \\
\hline group & B35 & -2.5657 & 0.2746 & -9.34 & $<.0001$ \\
\hline group & B50 & -2.8248 & 0.0771 & -36.62 & $<.0001$ \\
\hline group & $\mathrm{COO}$ & 0.1009 & 0.1548 & 0.65 & 0.5148 \\
\hline group & C15 & -1.0051 & 0.1548 & -6.49 & $<.0001$ \\
\hline group & C16 & 1.0433 & 0.1995 & 5.23 & $<.0001$ \\
\hline group & C17 & -3.1438 & 0.0699 & -45 & $<.0001$ \\
\hline group & C18 & 1.5814 & 0.1254 & 12.61 & $<.0001$ \\
\hline group & C19 & 0.4932 & 0.1254 & 3.93 & $<.0001$ \\
\hline group & $\mathrm{C} 22$ & 0.215 & 0.1503 & 1.43 & 0.1524 \\
\hline group & $\mathrm{C} 23$ & -0.5621 & 0.1503 & -3.74 & 0.0002 \\
\hline group & $\mathrm{C} 25$ & 0.5816 & 0.1761 & 3.3 & 0.001 \\
\hline group & C30 & -1.5224 & 0.1548 & -9.83 & $<.0001$ \\
\hline group & $\mathrm{C} 32$ & 0.1072 & 0.0699 & 1.54 & 0.1247 \\
\hline group & $\mathrm{C} 33$ & 2.2944 & 0.2359 & 9.73 & $<.0001$ \\
\hline group & C40 & -1.0449 & 0.0699 & -14.96 & $<.0001$ \\
\hline group & C43 & -0.6784 & 0.1663 & -4.08 & $<.0001$ \\
\hline group & C44 & -1.0424 & 0.0903 & -11.54 & $<.0001$ \\
\hline group & C45 & -0.2433 & 0.1826 & -1.33 & 0.1826 \\
\hline group & C50 & 1.9021 & 0.2945 & 6.46 & $<.0001$ \\
\hline group & C53 & -0.5014 & 0.1062 & -4.72 & $<.0001$ \\
\hline group & C54 & -0.0686 & 0.0699 & -0.98 & 0.3262 \\
\hline group & C56 & 0.4574 & 0.2212 & 2.07 & 0.0387 \\
\hline
\end{tabular}




\begin{tabular}{|c|c|c|c|c|c|}
\hline group & C58 & -6.1049 & 0.0699 & -87.39 & $<.0001$ \\
\hline group & C60 & 0.4257 & 0.1219 & 3.49 & 0.0005 \\
\hline group & C61 & 1.1126 & 0.2471 & 4.5 & $<.0001$ \\
\hline group & C62 & -1.3281 & 0.0699 & -19.01 & $<.0001$ \\
\hline group & C67 & 1.3201 & 0.1503 & 8.79 & $<.0001$ \\
\hline group & C71 & 0.6447 & 0.113 & 5.7 & $<.0001$ \\
\hline group & C81 & -0.8381 & 0.1219 & -6.88 & $<.0001$ \\
\hline group & C82 & 1.7234 & 0.2104 & 8.19 & $<.0001$ \\
\hline group & C91 & 1.7942 & 0.2285 & 7.85 & $<.0001$ \\
\hline group & D00 & -3.8818 & 0.1505 & -25.79 & $<.0001$ \\
\hline group & D10 & 0.7921 & 0.1415 & 5.6 & $<.0001$ \\
\hline group & D25 & -0.1562 & 0.0215 & -7.25 & $<.0001$ \\
\hline group & D34 & -2.9133 & 0.075 & -38.85 & $<.0001$ \\
\hline group & D50 & 1.3647 & 0.2231 & 6.12 & $<.0001$ \\
\hline group & D60 & 1.3677 & 0.0517 & 26.45 & $<.0001$ \\
\hline group & E10 & 1.8706 & 0.281 & 6.66 & $<.0001$ \\
\hline group & E65 & -1.294 & 0.0353 & -36.65 & $<.0001$ \\
\hline group & E70 & -2.2629 & 0.2162 & \begin{tabular}{|c|}
-10.47 \\
\end{tabular} & $<.0001$ \\
\hline group & F20 & 3.409 & 0.1179 & 28.92 & $<.0001$ \\
\hline group & F30 & 2.8989 & 0.2652 & 10.93 & $<.0001$ \\
\hline group & F40 & 1.406 & 0.2403 & 5.85 & $<.0001$ \\
\hline group & F70 & 2.1003 & 0.092 & 22.83 & $<.0001$ \\
\hline group & G00 & -0.4452 & 0.1837 & -2.42 & 0.0154 \\
\hline group & G20 & -0.2453 & 0.1755 & -1.4 & 0.162 \\
\hline group & G35 & -0.3603 & 0.1323 & -2.72 & 0.0065 \\
\hline group & G40 & 0.8444 & 0.2001 & 4.22 & $<.0001$ \\
\hline group & $\mathrm{HOO}$ & 0.9163 & 0.2048 & 4.47 & $<.0001$ \\
\hline group & $\mathrm{HO4}$ & -2.376 & 0.0215 & -110.32 & $<.0001$ \\
\hline group & $\mathrm{H} 10$ & -3.9111 & 0.2519 & -15.53 & $<.0001$ \\
\hline group & $\mathrm{H} 40$ & -0.76 & 0.1909 & -3.98 & $<.0001$ \\
\hline group & $\mathrm{H} 49$ & -2.7257 & 0.0085 & -319.79 & $<.0001$ \\
\hline group & $\mathrm{H} 65$ & -0.2071 & 0.161 & -1.29 & 0.1984 \\
\hline group & 100 & -5.4773 & 0.0232 & -235.62 & $<.0001$ \\
\hline group & 105 & -3.8066 & 0.0232 & -163.75 & $<.0001$ \\
\hline group & 110 & 1.7462 & 0.3453 & 5.06 & $<.0001$ \\
\hline group & 120 & 3.1907 & 0.2686 & 11.88 & $<.0001$ \\
\hline group & 121 & 1.9182 & 0.2179 & 8.8 & $<.0001$ \\
\hline group & 126 & -0.2474 & 0.0232 & -10.64 & $<.0001$ \\
\hline group & 160 & -0.8378 & 0.0364 & -23.04 & $<.0001$ \\
\hline group & 161 & 0.5443 & 0.0232 & 23.41 & $<.0001$ \\
\hline group & 163 & -0.3234 & 0.0699 & -4.63 & $<.0001$ \\
\hline group & 164 & 2.9525 & 0.0763 & 38.69 & $<.0001$ \\
\hline group & 170 & -0.3442 & 0.0235 & -14.62 & $<.0001$ \\
\hline group & 171 & 1.1464 & 0.1315 & 8.72 & $<.0001$ \\
\hline group & 174 & -1.6058 & 0.0235 & -68.22 & $<.0001$ \\
\hline
\end{tabular}




\begin{tabular}{|c|c|c|c|c|c|}
\hline group & 180 & 0.2972 & 0.0232 & 12.78 & $<.0001$ \\
\hline group & 183 & -0.6599 & 0.0232 & -28.39 & $<.0001$ \\
\hline group & 184 & -0.7641 & 0.0232 & -32.87 & $<.0001$ \\
\hline group & 100 & 0.5101 & 0.274 & 1.86 & 0.0627 \\
\hline group & $\mathrm{J09}$ & -3.9719 & 0.0444 & -89.47 & $<.0001$ \\
\hline group & $\mathrm{J} 12$ & 1.9576 & 0.2803 & 6.98 & $<.0001$ \\
\hline group & $J 20$ & 1.034 & 0.2781 & 3.72 & 0.0002 \\
\hline group & $J 30$ & 0.0726 & 0.1848 & 0.39 & 0.6947 \\
\hline group & $\mathrm{J31}$ & -0.9308 & 0.2057 & -4.52 & $<.0001$ \\
\hline group & $\mathrm{J33}$ & 0.4669 & 0.0215 & 21.68 & $<.0001$ \\
\hline group & $J 40$ & 2.428 & 0.2889 & 8.4 & $\mid<.0001$ \\
\hline group & $\mathrm{J} 80$ & 2.4768 & 0.0906 & 27.34 & $<.0001$ \\
\hline group & KOO & -0.1067 & 0.0828 & -1.29 & 0.1974 \\
\hline group & K20 & 0.2262 & 0.231 & 0.98 & 0.3275 \\
\hline group & K50 & 3.1417 & 0.1874 & 16.76 & $<.0001$ \\
\hline group & K55 & -0.8339 & 0.0906 & -9.21 & $<.0001$ \\
\hline group & K70 & 0.832 & 0.0562 & 14.8 & $<.0001$ \\
\hline group & LOO & 1.3812 & 0.2626 & 5.26 & $<.0001$ \\
\hline group & L10 & 1.7329 & 0.3036 & 5.71 & $<.0001$ \\
\hline group & M00 & 2.7793 & 0.309 & 8.99 & $<.0001$ \\
\hline group & M40 & 2.2359 & 0.1869 & 11.97 & $<.0001$ \\
\hline group & M80 & -0.5344 & 0.2185 & -2.45 & 0.0145 \\
\hline group & NOO & 3.6792 & 0.3284 & 11.2 & $<.0001$ \\
\hline group & $\mathrm{N} 40$ & 1.6461 & 0.1821 & 9.04 & $<.0001$ \\
\hline group & N41 & 0.5307 & 0.2382 & 2.23 & 0.0259 \\
\hline group & N46 & -4.1802 & 0.075 & -55.74 & $<.0001$ \\
\hline group & N70 & -1.8539 & 0.0594 & -31.19 & $<.0001$ \\
\hline group & N71 & -1.1125 & 0.2179 & -5.1 & $<.0001$ \\
\hline group & N80 & 1.6696 & 0.161 & 10.37 & $<.0001$ \\
\hline group & N97 & -4.0472 & 0.0887 & -45.64 & $<.0001$ \\
\hline group & 003 & -0.1824 & 0.0215 & -8.47 & $<.0001$ \\
\hline group & Q10 & 0.1989 & 0.0215 & 9.24 & $<.0001$ \\
\hline group & Q20 & 0 & 0 & & 1 \\
\hline Intercept & & 10.3275 & 0.0372 & 277.36 & $<.0001$ \\
\hline
\end{tabular}

